\title{
ColXV promotes adipocyte differentiation via inhibiting DNA methylation and cAMP/PKA pathway in mice
}

\author{
Guannv Liu ${ }^{1,}{ }^{*}$, Meihang $\mathrm{Li}^{1,}{ }^{1}$, Yatao $\mathrm{Xu}^{1}{ }^{1}$, Song Wu${ }^{1}$, Muhammad Saeed ${ }^{1}$ and Chao Sun ${ }^{1}$ \\ ${ }^{1}$ College of Animal Science and Technology, Northwest A and F University, Yangling, Shaanxi, 712100, China \\ *These authors contributed equally to this work \\ Correspondence to: Chao Sun, email: sunchao2775@163.com \\ Keywords: ColXV, adipocyte differentiation, CREB, methylation, CAMP/PKA pathway \\ Received: April 12, 2017 Accepted: June 04, $2017 \quad$ Published: June 16, 2017 \\ Copyright: Liu et al. This is an open-access article distributed under the terms of the Creative Commons Attribution License 3.0 (CC BY 3.0 ), \\ which permits unrestricted use, distribution, and reproduction in any medium, provided the original author and source are credited.
}

\section{ABSTRACT}

Extracellular matrix (ECM), as an essential component of adipose tissue, not only provides mechanical support for adipocyte growth, but also participates in ECMadipocyte communication via various secreted proteins, including highly enriched collagens. Collagen XV (ColXV) is a secreted non-fibrillar collagen within ECM Basement Membrane (BM) zones and well recognized as a tumor suppressor. However, the role of ColXV in adipose tissue is still unknown. In this study, high fat diet (HFD) fed mice were used as obese model, in which we deeply investigated the interaction between CoIXV and adipocyte differentiation or adipose metabolism. We found great elevated ColXV expression and positive effect of CoIXV on lipid deposition during adipocyte differentiation or obesity both in vitro and in vivo. CAMP response element binding protein (CREB) is a cellular transcription factor that can inhibit adipogenesis and promote lipolysis. Here we proposed ColXV as a newly discovered downstream gene of CREB. We further proved that CREB can repress adipocyte differentiation and enhance lipolysis by negatively regulating ColXV transcription. Mechanistic studies showed ColXV enhanced adipocyte differentiation and lipid deposition through reducing its DNA methylation and repressing the CAMP/PKA signaling pathway. Collectively, our study identified ColXV as a novel downstream gene for CREB and could promote adipocyte differentiation, inhibit lipolysis through repressing CAMP / PKA signaling pathway and positively regulating adipogenic markers expressions by repressing the activity of maintenance methyltransferase Dnmt1. Our data discovered a novel role of ColXV in adipocyte differentiation and provide insight into obesity and related metabolic diseases.

\section{INTRODUCTION}

The increasing obesity and obesity-related diseases such as insulin resistance and type II diabetes are closely associated with excessive fat deposition [1-3]. Adipose tissues, which mainly consist of adipocytes, are important in balancing systemic energy levels. Two general classes of adipose tissues are found in mammals: white and brown. White adipose tissue (WAT) stores energy in the form of fatty acids in response to systemic demands, while brown adipose tissue (BAT) burns substrates, including fatty acids and glucose, to produce heat in response to various stimuli. Adipose tissue grows through hyperplasia and/or hypertrophy, which results in increasing adipocytes number and differentiating into fat-laden adipocytes. CCAAT/ enhancer-binding proteins (C/EBPs) and peroxisome proliferator activated receptor $\gamma(\operatorname{PPAR} \gamma)$ are considered as central engine for adipocyte differentiation [4]. Cyclic adenosine monophosphate (cAMP) and cAMP-dependent protein kinase A (PKA) signaling pathway are involved in lipogenesis and lipolysis process. Studies implicated activated PKA directly phosphorylates the transcription 
factor cyclic AMP responsive element binding protein (CREB), which promotes the expressions of lipolysis and thermogenic genes such as peroxisome proliferator $\gamma$-activated receptor coactivator $1-\alpha \quad(\operatorname{Pgc}-1 \alpha)$ and uncoupling protein 1 (Ucp1) in adipocytes $[5,6]$.

Extracellular matrix (ECM) is a non-cellular threedimensional macromolecular network composed of collagens, proteoglycans/glycosaminoglycans, elastin, fibronectin, laminins, and several other glycoproteins [7]. ECM located in the basement membrane of adipose tissues, are involved in adipose development, expansion and metabolism, even obesity and insulin resistance [8-10]. Collagen XV (ColXV, encode by Col15 $\alpha 1$ gene), one member of collagen family, belongs to the category of MULTIPLEXINs/endostatin-producing collagens together with collagen XVIII (ColXVIII) [11, 12]. With similar structure that a central triple helical collagenous domain is interrupted by several non-collagenous (NC) domains, MULTIPLEXINs function similarly on angiogenesis, inflammation, tumorigenesis and adipose metabolism [13-15]. Studies show that ColXVIII promotes lipid deposition in adipose tissue and also causes hypertriglyceridemia in mice and human [16-18]. ColXV was primarily recognized as an important tumor suppressor [19], but was also found highly expressed in adipocytes and adipose tissues [20, 21]. However, the function of ColXV in adipocyte differentiation and its molecular mechanism have not been established.

In present study, we found that ColXV expression was increased during adipocyte differentiation and also accentuated in adipose tissues of HFD fed mice. ColXV further accelerated lipid deposition in obese mice. ColXV strengthened adipocyte differentiation and weakened lipolysis in adipocytes. Moreover, we found ColXV promoted adipocyte differentiation through negative CREB transcription, DNA methylation inhibition and inhibiting cAMP/PKA signal pathway. Our findings illustrate a novel function of ColXV in adipocyte differentiation and energy balance and ColXV may also serve as a potential drug target for obesity related diseases.

\section{RESULTS}

\section{ColXV expression was increased in obese adipose tissues and mature adipocytes}

We firstly detected the expression profile of ColXV in mice tissues and organs. Result showed ColXV mRNA level was higher in adipose tissues, compared with the expressions in liver, heart and muscle (Figure 1A). Among different adipose tissues, ColXV expressions in inguinal white adipose tissue (iWAT) and epididymis white adipose tissue (eWAT) were significantly higher than that in interscapular brown adipose tissue (BAT) (Figure 1A). To determine whether high fat diet (HFD)induced obesity impacts ColXV expression, mice were fed with HFD (60 kcal\% fat) or chow diet (10 kcal\% fat). Higher mouse body weight and food intake were observed in mice with HFD feeding for 9 weeks (Supplementary Figure 1A and 1B). Followed by elevated adipogenic markers PPAR $\gamma$, FABP4 and decreased thermogenic gene UCP1 in HFD fed mice (Figure 1C), ColXV mRNA level was robustly increased in mouse BAT, iWAT and eWAT (Figure 1B). ColXV expression was positively correlated with PPAR $\gamma$ and FABP4 in iWAT and eWAT, but negatively correlated with UCP1 in BAT (Figure 1D-1F). In primary cultured adipocytes, along with the elevation of adipogenic markers, ColXV mRNA level was increased during adipocyte differentiation (Figure 1G). Overall, ColXV is highly increased in obese adipose tissues and mature adipocytes, which implicate ColXV may contribute to adipocyte differentiation and adipose metabolism.

\section{ColXV accelerated lipid deposition in obese mice}

To investigate the effects of ColXV on obesity, we intraperitoneally injected ColXV overexpressed adenovirus vector into chow and HFD fed mice. We noted that ColXV mRNA and protein expressions were significantly increased after ColXV vector injection in both chow and HFD fed mice as expected (Figure 2A and 2B), and it expressed specifically in adipose tissues (Supplementary Figure 2A). HFD fed mice showed elevated body weight and food intake relative to chow diet mice after 5 weeks, which were both strengthened in ColXV overexpressed group (Figure 2C and Supplementary Figure 2B). Then we analyzed body composition and found Col XV overexpression had a similar effect with HFD feeding, both increased the fat mass, but no effects on lean mass (Figure 2D). ColXV overexpression increased serum lipids like triglyceride (TG), total cholesterol (TC) and low-density lipoprotein (LDL-C), but decreased high density lipoprotein (HDL-C), more obvious in HFD mice (Supplementary Figure 2C). In HFD fed mice, TG level of eWAT also exhibited significantly higher while free fatty acid (FFA) was lower when ColXV overexpressed (Supplementary Figure 2D and 2E). In addition, the increased mRNA level of adipogenic markers C/EBP $\beta$, PPAR $\gamma$ and FABP4 by HFD were also strengthened in ColXV overexpressed group (Supplementary Figure 2F). Adipose tissue lipid metabolism related enzymes, such as fatty acid synthase (FASN) and acetyl coenzyme acarboxylase (ACC $\alpha$ ) protein expressions were higher in Ad-Col15al group, while the phosphorylation of adipose triglyceride lipase (ATGL) and hormone sensitive lipase (HSL) were lower (Figure 2E). ELISA measurement of FASN, ACC $\alpha$, ATGL and HSL showed the consistent results (Supplementary Figure 2G). Above results indicate ColXV is a positive regulator in mouse fat deposition, which could both accelerate lipid synthesis and weaken lipolysis in vivo. 


\section{ColXV promoted cell differentiation in mice adipocytes}

We next addressed whether ColXV elicits accelerated effects on adipocyte differentiation and lipid synthesis in vitro. ColXV overexpression vector AdCol15 $\alpha 1$ and interference vector sh-Col15 $\alpha 1$ were used to control ColXV expression, Ad-GFP as control. There were no difference between Ad-GFP and negative control on ColXV expression, and Ad-Col15 $\alpha 1$ and sh-Col15 1 were functional (Supplementary Figure 3A and 3B). We found overexpressing ColXV increased both mRNA levels (Figure 3A-3D) and protein levels (Figure 3E) of C/EBP $\beta, \mathrm{C} / \mathrm{EBP} \alpha$, PPAR $\gamma$ and FABP4 after $0 \mathrm{~d}, 4 \mathrm{~d}$ and $8 \mathrm{~d}$ differentiation and ColXV promoted adipocyte differentiation more remarkable in middle and later period. Greater amount of lipid droplets of adipocytes in ColXV overexpressed group relative to control were seen as determined by Bodipy staining, which was opposite to ColXV interference group (Figure 3F). These results mean ColXV promoted mice adipocyte differentiation mostly in middle and later stage.

\section{ColXV weakened isoproterenol-induced lipolysis in mice adipocytes}

To better understand the role of ColXV in adipocyte metabolism, we measured the expressions of lipogenesis and lipolysis genes in later differentiated stage. Overexpressed ColXV accelerated both the mRNA levels (Supplementary Figure 3C) and protein levels (Supplementary Figure 3D) of lipid synthesis genes, such as FASN and ACC $\alpha$, while

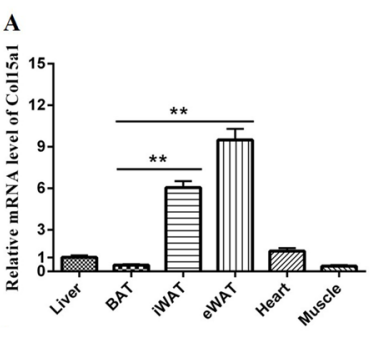

C

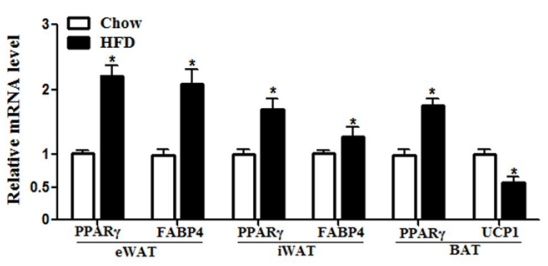

B

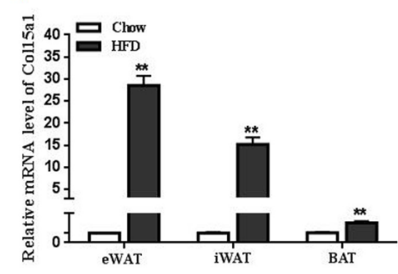

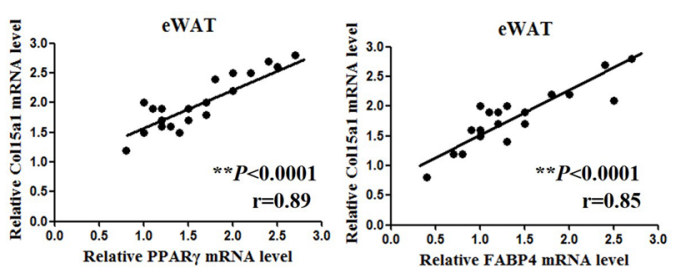
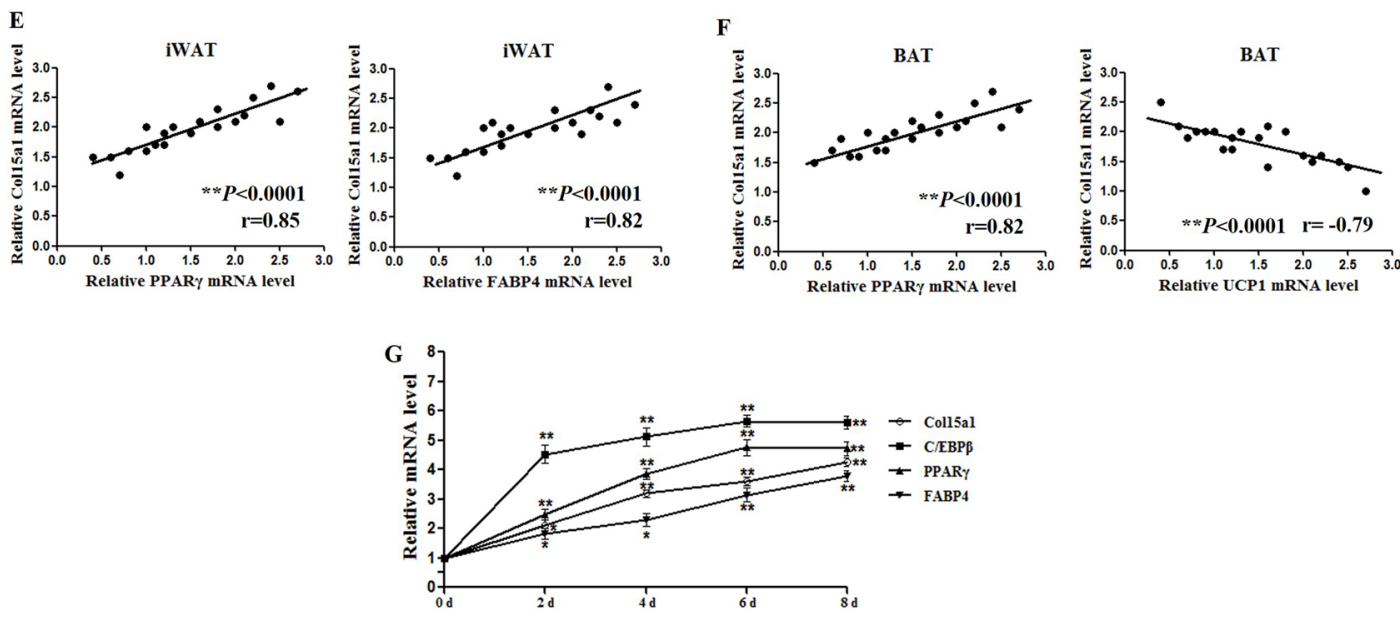

Figure 1: ColXV expression was increased in obese adipose tissues and mature adipocytes. (A) Male mice of 8-10 weeks old fed with chow diet were sacrificed. ColXV mRNA level was detected in liver, BAT, iWAT, eWAT, heart and muscle $(n=6)$. To detect ColXV mRNA (B) and other adipogenic markers mRNA levels (C) in adipose tissues of obese individuals, mice were fed with HFD for 9 weeks before isolating iWAT, eWAT and BAT. Chow diet feeding mice were used as control $(n=8)$. Correlation between mRNA expression of adipogenic markers on the x-axis and mRNA expression of ColXV on the y-axis in eWAT (D) iWAT (E) and BAT (F) $(n=3)$. (G) Pre-adipocytes were acquired from four-week-old lean mice and induced into mature adipocytes. Relative mRNA levels of ColXV and adipogenic markers were detected in different time points during adipocyte differentiation $(n=6)$. Data represent the mean \pm SEM of three independent experiments. ${ }^{*} P<0.05,{ }^{* *} P<0.01$. 
declined both mRNA level and phosphorylation of lipolysis genes, like HSL and ATGL. Isoprenaline (ISO), an adrenergic receptor agonist, has been used to induce lipolysis [22]. We treated adipocytes with ISO, intend to investigate the function of ColXV in ISO-induced lipolysis. Ablated effects were found with ISO treatment in ColXV over-expressed adipocytes, such as enhanced lipid droplet formation (Figure 4A), elevated dissociative TG level and decreased dissociative FFA level (Figure 4B). Overexpression of ColXV also blunted the lipolysis effect of ISO by rescuing the decreased FASN and ACC $\alpha$ level and repressing the increase of HSL and ATGL from both mRNA (Figure 4C) and protein phosphorylation level (Figure 4D). Our findings are consistent with previous studies that HSL and ATGL are phosphorylated in ISO-induced lipolysis process, at serine 660 for HSL [23] and at serine 406 for ATGL [22]. Our data revealed that ColXV enhanced adipocyte lipid synthesis and weakened ISO-induced lipolytic activity.

\section{CREB attenuated ColXV transcription in adipocyte differentiation and lipolysis}

In order to analyze the underlying mechanisms of ColXV on adipocyte differentiation and metabolism, we determined the transcription-level regulation. With Genomatix software analysis, CREB was found to be one of transcription factors of ColXV promoter (Supplementary Figure 4A), on which there were two potential cAMP response elements (CREs) for CREB binding, $-354 \mathrm{bp} \sim-334 \mathrm{bp}$ and $-780 \mathrm{bp} \sim-760 \mathrm{bp}$ upstream of transcription start site on ColXV promoter (Figure 5A). Then we carried out dual-luciferase reporter assay to verify the result of software prediction. For plasmids carrying the two binding regions and only -354 bp $\sim-334$ bp region, when CREB was induced by forskolin, luciferase activity was lower than DMSO control (Figure 5B), which means both of the two regions could be functional and CREB has a negative role in regulating ColXV promoter activity. Further we used sitedirected mutation to specify which binding site is critical for CREB regulation. When site $-780 \mathrm{bp} \sim-760 \mathrm{bp}$ was mutated, the blocking effect of ColXV transcription was still exist by Forskolin treatment, but when mutated the other binding site $-354 \mathrm{bp} \sim-334 \mathrm{bp}$ the blocking effect disappeared (Figure 5C). This implicated that the region $-354 \mathrm{bp} \sim-334 \mathrm{bp}$ is the functional binding site of CREB. Thus we suppose CREB may repress ColXV transcription and block its promoting function in adipocyte differentiation and metabolism. Adipocytes were overexpressed or interfered with ColXV and treated with Forskolin. Data showed CREB was successfully induced with Forskolin treatment (Supplementary Figure 4B) and CREB elevation blocked the transcription of ColXV (Figure 5D). Then, the elevated protein expressions of C/ EBP $\beta$, PPAR $\gamma$, FABP4, and decreased phosphorylation level of ATGL caused by ColXV overexpression were
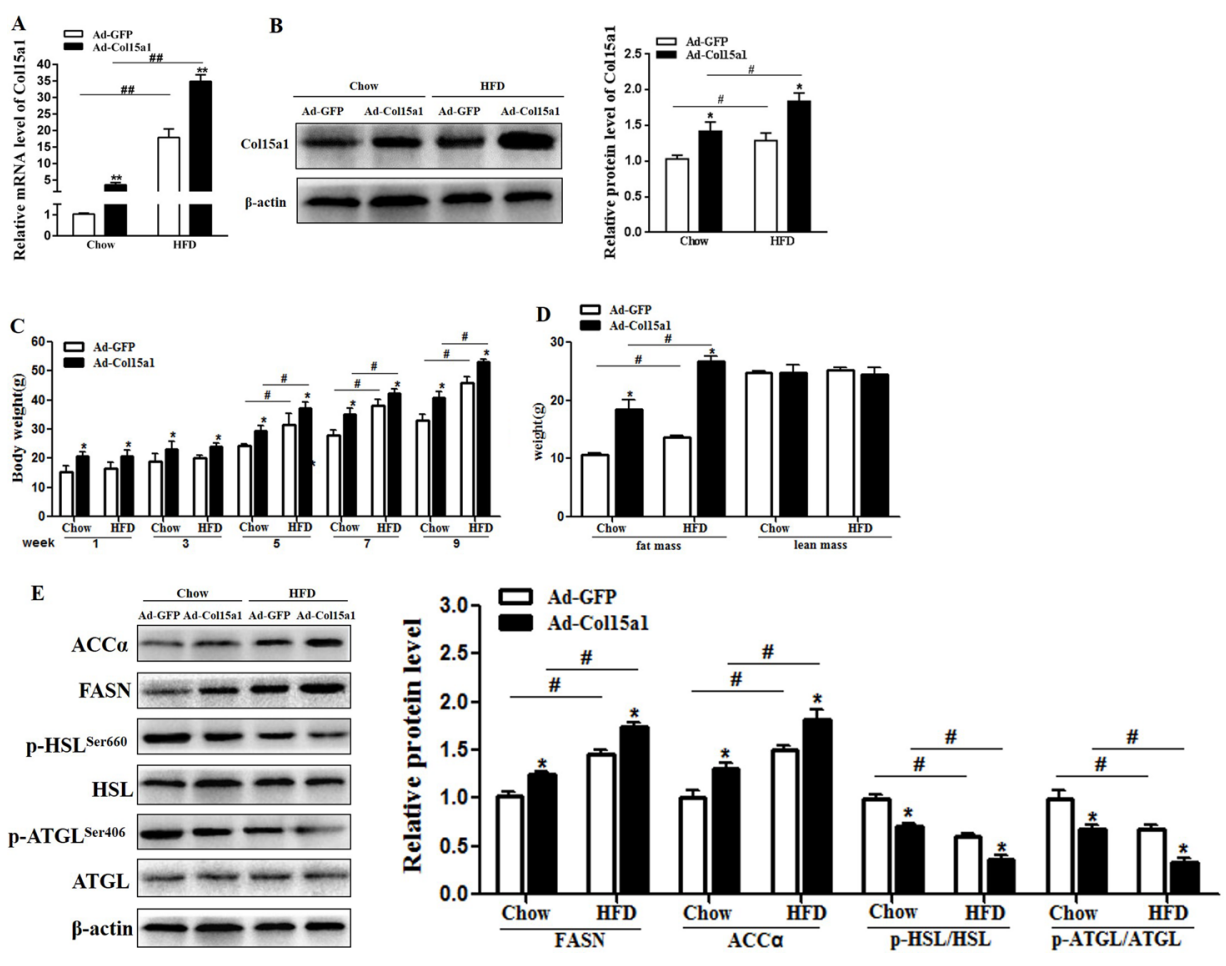

Figure 2: ColXV accelerated lipid deposition in obese mice. Mice fed with chow and HFD diet were intraperitoneal injected with Ad-Col15 $\alpha 1$ or Ad-GFP, then ColXV mRNA level (A) and protein level (B) were detected in eWAT of mice. Body weight (C) and body mass (D) were monitored each week. (E) Protein levels of ACC, FASN and phosphorylation level of HSL and ATGL were also detected in mice eWAT $(n=6)$. Data represent the mean \pm SEM of three repeats. ${ }^{* *} P<0.05,{ }^{* * \# \#} P<0.01$. 
greatly repressed by Forskolin treatment (Figure 5E). The mRNA expressions of C/EBP $\beta$, PPAR $\gamma$, FABP4 and ATGL presented the same trend (Supplementary Figure 4C). Thus, our findings showed that ColXV increased adipocyte differentiation and inhibited lipolysis through CREB negative transcription.

\section{ColXV enhanced adipocyte differentiation and weakened lipolysis via reducing DNA methylation}

DNA methylation downregulates gene transcription by controlling transcription start sites regulated by methyltransferase 1 (Dnmt1) [24]. Thus we studied DNA methylation of ColXV in adipocyte differentiation, also intended to clarify the relationship between ColXV and Dnmt1. Two methylation regions were predicted in ColXV DNA sequence with Laboratory of Molecular Medicine website, 5 CpGs present in ColXV promoter and $20 \mathrm{CpGs}$ in the intron 1, respectively (Figure 6A). In this study, we found most methylation sites both in promoter and intron 1 of ColXV in differentiated mature adipocytes were lowly methylated compared with that in un-differentiated adipocytes (Figure 6A, Supplementary Figure 5A and 5B). This is consistent with our previous finding that ColXV expression was increased during adipocyte differentiation. To further investigate how DNA methylation function on ColXV regulated adipocyte differentiation and lipolysis, we treated adipocytes with 5-aza-2'-deoxycytidine (5-Aza-dC), a pharmacological inhibitor of Dnmtl to induce
A

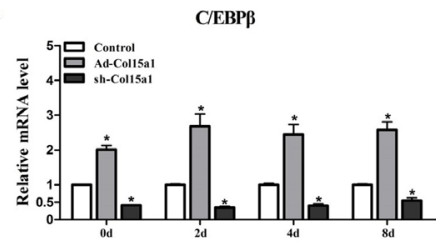

C

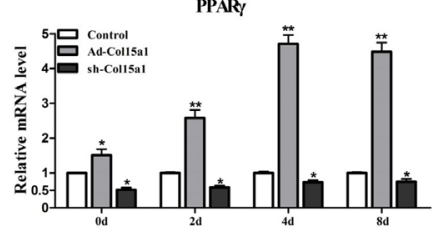

B

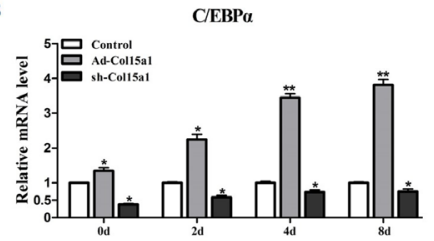

D

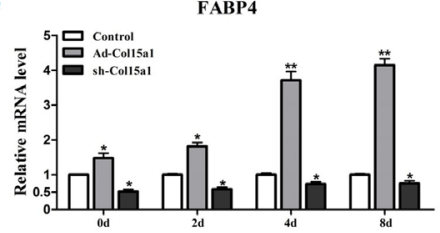

$\mathbf{E}$

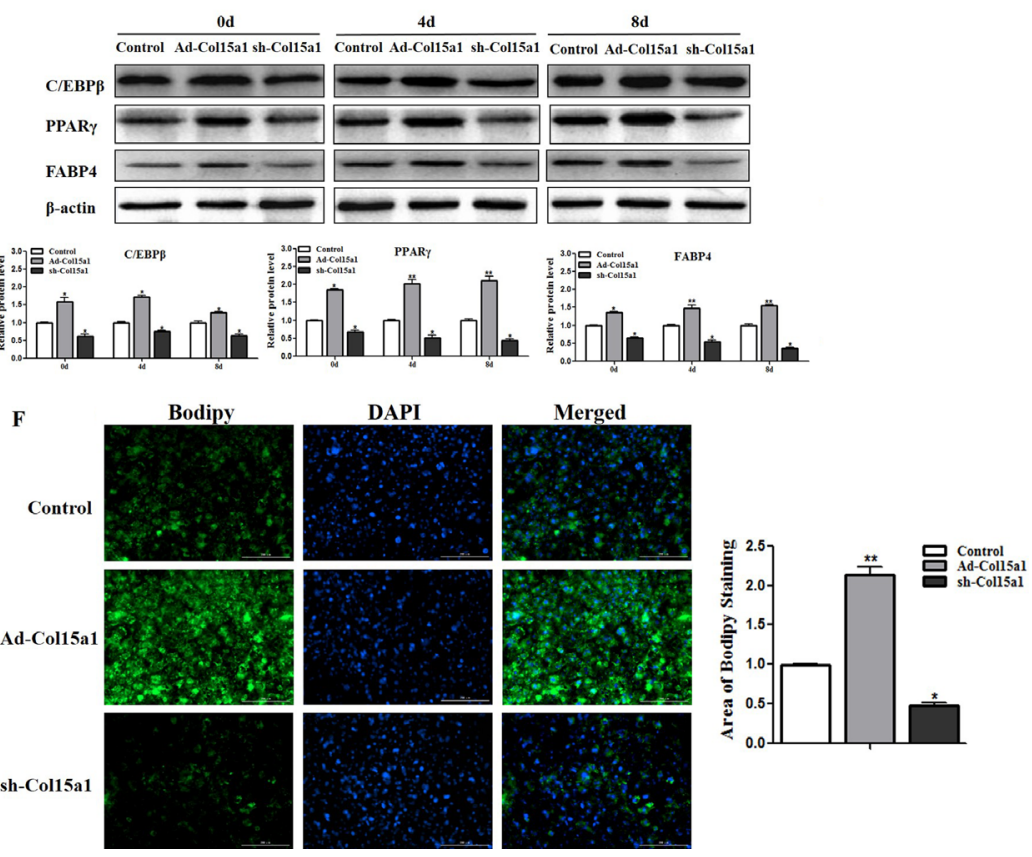

Figure 3: ColXV promoted cell differentiation in mice adipocytes. Mice pre-adipocytes were infected with adenovirus overexpressed ColXV (Ad-Col15 $\alpha 1$ ), adenovirus interfered ColXV (sh-Col15 $\alpha 1$ ) or control (Ad-GFP) and then induced into mature adipocytes. On day 0 , day 2, day 4 and day 8 of differentiation, mRNA levels of C/EBP $\beta$ (A) C/EBP $\alpha(\mathbf{B})$ PPAR $\gamma(\mathbf{C})$ and FABP4 (D) were measured respectively $(n=6)$. (E) C/EBP $\beta$, PPAR $\gamma$ and FABP4 protein levels were detected on day 0 , day 4 and day 8 of differentiation and quantified according to band density $(n=6)$. (F) Bodipy staining and quantitative analysis of lipid droplets in Ad-Col15 1 , sh-Col15 1 and control infected adipocytes $(n=6)$. Data represent the mean \pm SEM of triplicate. ${ }^{*} P<0.05,{ }^{* * \# \#} P<0.01$. 

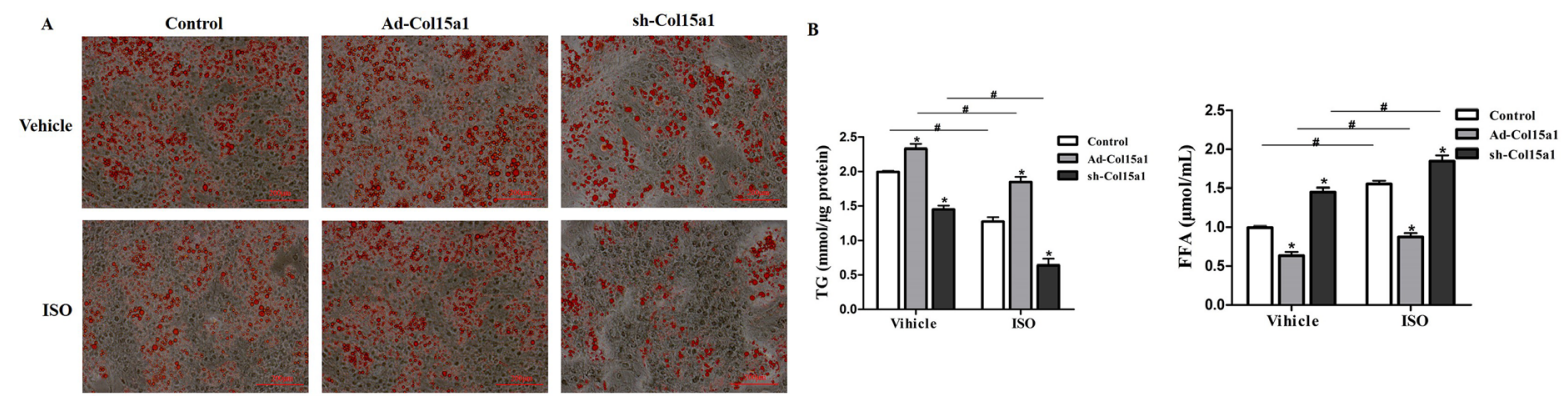

C

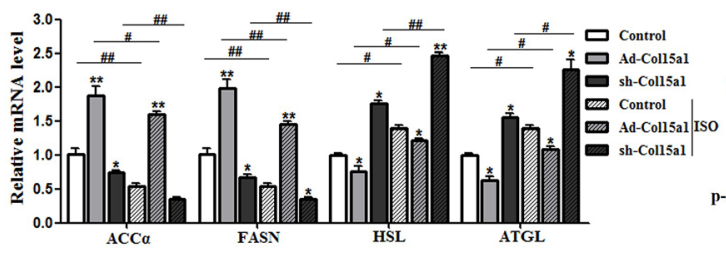

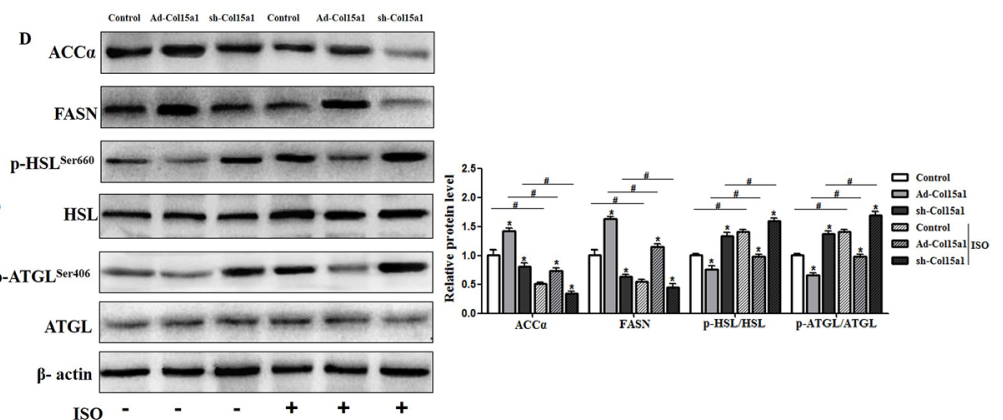

Figure 4: ColXV weakened isoproterenol-induced lipolysis in mice adipocytes. Mice adipocytes were infected with AdCol15a1, sh-Col15 $\alpha 1$ or control. Oil Red O staining (A) were carried out in mature adipocytes with respective treatment mentioned above $(n=6)$. Base on infections with different adenovirus, cells were treated with ISO or its vehicle DMSO. Then, TG and FFA concentration (B) relative mRNA levels of ACC $\alpha$, FASN, ATGL, HSL (C) relative protein level of ACC $\alpha$, FASN (D) and ATGL, HSL phosphorylation levels were all detected and quantified $(n=6)$. Data represent the mean \pm SEM of three repeats. ${ }^{* \#} P<0.05,{ }^{* * \#} P<0.01$.
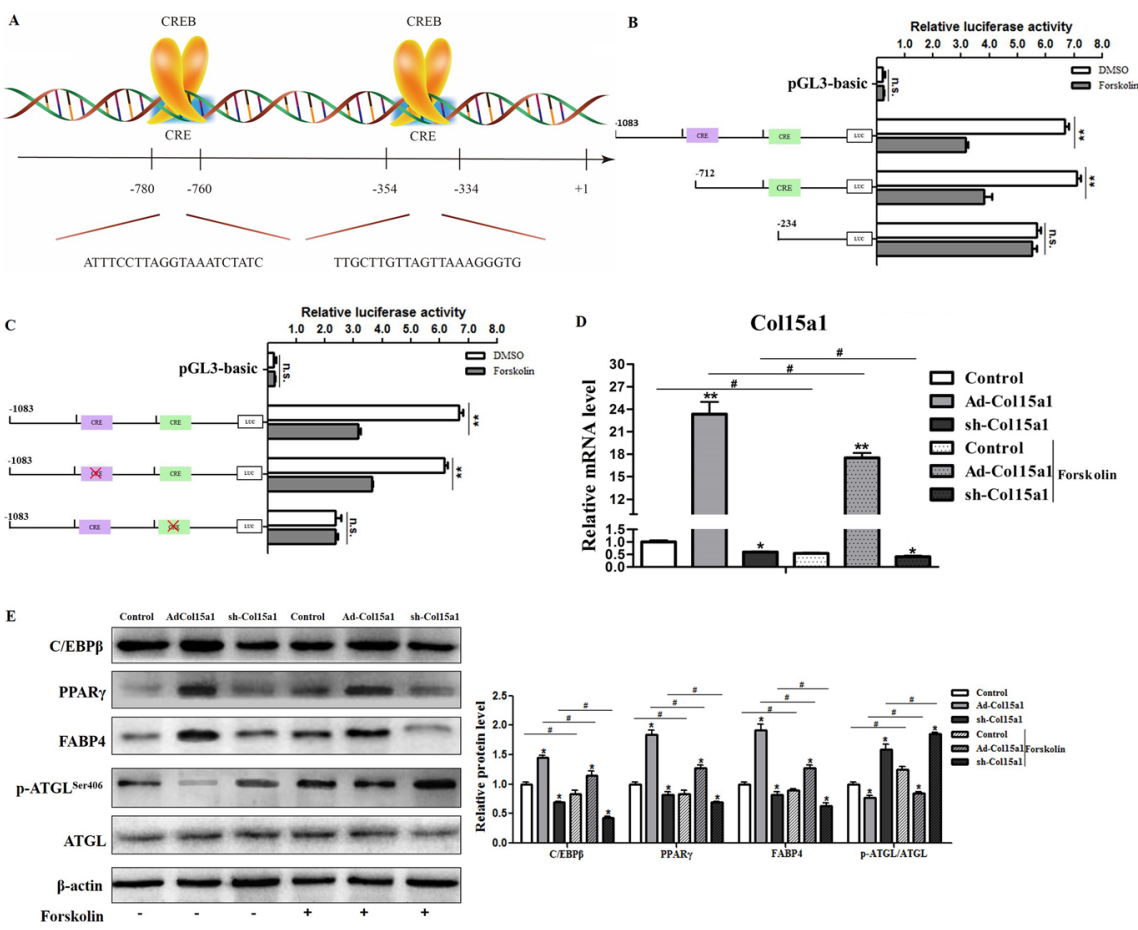

Figure 5: CREB attenuated ColXV transcription in adipocyte differentiation and lipolysis. CREB was selected as candidate transcription regulator for ColXV according to analyzing results in Genomatix software. (A) The schematic diagram of CREB binding sites on ColXV promoter. Luciferase reporter gene fused ColXV promoter fragments (B) or mutated the CREB binding sites on ColXV promoter fragments $(\mathbf{C})$ were transfected into cells with or without Forskolin treatment $(n=6)$. Luciferase activity was detected and corrected with Renilla luciferase activity $(n=6)$. To explore the function of CREB on ColXV expression, Forskolin was added in cells overexpressed or interfered ColXV, then relative ColXV mRNA level (D) were measured, together with protein levels of adipogenic genes, such as C/EBP $\beta$, PPAR $\gamma$, FABP4 and ATGL $(\mathbf{E})$ were detected $(n=6)$. Data represent the mean \pm SEM of triplicate. ${ }^{* *} P<0.05,{ }^{* * \# \#} P<0.01$. 
demethylation [24]. Maintain methyltransferase Dnmt1 activity was inhibited by 5 -Aza-dC both in pre-adipocytes and differentiated adipocytes, and ColXV overexpression group had a similar effect (Figure 6B). However, de novo methyltransferases Dnmt3a and Dnmt3b activity were unaffected in ColXV or 5-Aza-dC treatment (Supplementary Figure 5C). Adding of 5-Aza-dC reduced the methylation levels in both promoter and intron 1 of ColXV (Supplementary Figure 5D and 5E), which correspondingly elevated ColXV mRNA level (Figure 6C). Then we analyzed the expressions of adipogenic and lipolytic markers after infecting adipocytes with Ad-Col15 $\alpha 1 / \mathrm{sh}$ Col15 $\alpha 1$ or treating with 5-Aza-dC. In early differentiation period, ColXV promoted C/EBP $\beta$ and PPAR $\gamma$ mRNA expressions, while 5-Aza-dC inhibited them (Figure 6D), which is opposite with later stage differentiation. This can be explained by the inhibitory effect of 5-Aza-dC on adipogenesis in early differentiation stage [25]. Lipolytic markers, such as HSL and ATGL mRNA expressions were all blunted after either ColXV overexpression or adding 5-Aza-dC, regardless of early or later differentiation period (Figure 6E). Similarly, enhanced lipid droplet formation (Supplementary Figure 5F), elevated TG level and decreased

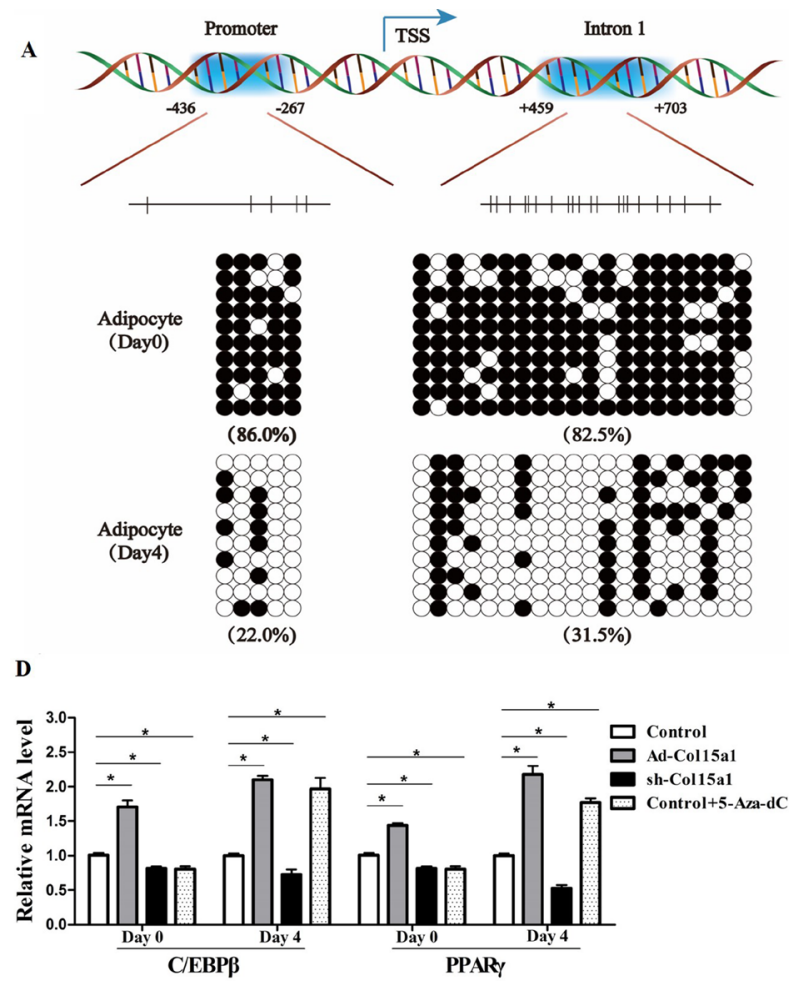

FFA level (Supplementary Figure 5G) were observed in 5-Aza-dC, also similar to ColXV forced expression group. Our results suggested that ColXV has a similar effect with 5-Aza-dC on DNA demethylation and this can be one mechanism in ColXV induced adipocyte differentiation and weakened lipolysis.

\section{cAMP/PKA signal pathway was essential for effects of ColXV on adipocyte differentiation and lipolysis}

To clear the molecular mechanism underling the regulation of ColXV and CREB on adipocyte differentiation, we studied the function of cAMP/PKA signal pathway in CREB-ColXV mediated adipocyte metabolism using pathway activator and inhibitor. When cAMP/PKA signal pathway was activated by Forskolin, key factors in cAMP/PKA signal pathway such as cAMP (Figure 7A), CREB and p-PKA (Figure 7B) were correspondingly increased, while pathway inhibitor H89 brought the opposite effects (Figure 7C and 7E), which means the cAMP/PKA signal pathway was successfully activated or inhibited.

B
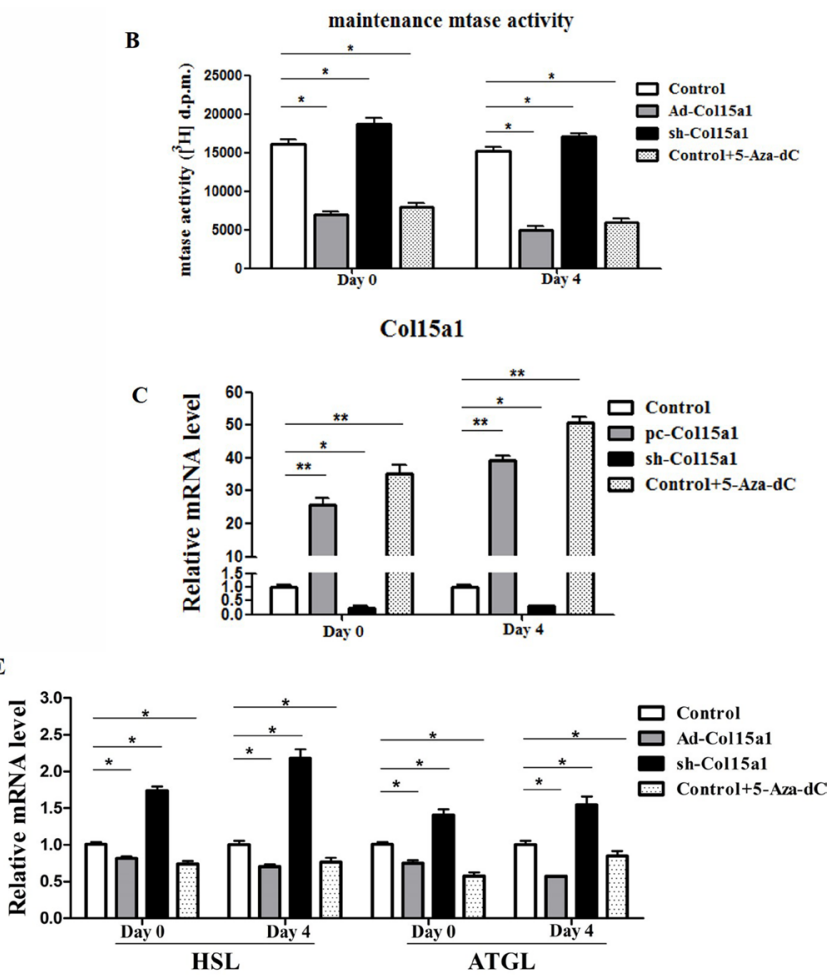

Figure 6: ColXV enhanced adipocyte differentiation and weakened lipolysis via reducing DNA methylation. (A) Bisulphite sequencing analyses of the ColXV DNA. The methylation sites on promoter and intron 1 of ColXV are depicted. The CpGs in each region are represented with vertical bars. Methylation status of adipocytes was analyzed before (day 0 ) and after (day 4) differentiation induction $(n=3)$. Methylation status of the $\mathrm{CpGs}$ within each amplified regions were represented with closed circle (methylated) and open circle (unmethylated). (B) Maintenance methyltransferase (mtase) Dnmt1 activity was detected in control, Ad-Col15 $\alpha 1$, sh-Col15 $\alpha 1$ or 5-Aza$\mathrm{dC}$ treated adipocytes, either on day 0 or day 4 after differentiation $(n=3)$. 5-Aza-dC or overexpressed and interfered with ColXV treated adipocytes, then relative Col15 1 mRNA level (C) were measured. Relative mRNA levels of C/EBP $\beta$, PPAR $\gamma(\mathbf{D})$ and HSL, ATGL (E) were also detected. Data represent the mean \pm SEM of three independent experiments. ${ }^{* \#} P<0.05,{ }^{* * * \# P} P<0.01$. 
We found ColXV overexpression promoted adipocyte differentiation by elevating adipogenic markers $\mathrm{C} / \mathrm{EBP} \beta$ and FABP4 protein levels, reducing lipolytic marker ATGL phosphorylation. While adding of Forskolin could negatively regulate the effects caused by ColXV and the anti-differentiation effect of ColXV interference was found enhanced by Forskolin (Figure 7D). When cAMP/ PKA signaling pathway is inhibited by H89, the differentiation inducement effect of ColXV overexpression was further enhanced and the anti-differentiation effect of ColXV interference was weakened (Figure 7F). Hence, these data indicated the effect of ColXV in increasing adipocyte differentiation and decreasing lipolysis was by inhibiting cAMP/PKA signal pathway.

\section{DISCUSSION}

ECM is an important multifunctional molecular content, which provides structural support to tissues and organs, modifies inter/extracellular signals, and regulates essential cellular functions [7-10]. Studies indicated that excessive accumulation or inappropriate remodeling of ECM in adipose tissues may lead to obesity or even adipose dysfunction [26-28]. ECM components especially collagens play an important role in adipose metabolism. Collagens turnover in pre-adipocyte differentiation through metalloproteinases (MMPs) and their tissue inhibitors (TIMPs) regulate adipose tissue remodeling and wholebody lipid distribution [29]. Different collagen components were secreted in various stages of adipocyte differentiation [30]. In this study, we demonstrated that ColXV expression was elevated in mature adipocytes and adipose tissues of HFD fed mice, the higher expression could further accelerate lipid deposition in obese mice. This is consistent with previous report that proteome ColXV is up-regulated during adipogenesis in a temporal fashion [31]. ColXV and ColXVIII are considered as MULTIPLEXINs/ endostatin-producing collagens. Previous studies have shown ColXVIII directly regulate adipocyte differentiation, fat deposition and lipolysis [16-18]. Here, we found ColXV promoted adipocytes differentiation mostly in middle and later stage and in the meantime, enhanced adipocyte lipid synthesis and weakened ISO-induced lipolysis.

CREB is a well-documented transcription factor involved in adipocyte differentiation and lipid metabolism.
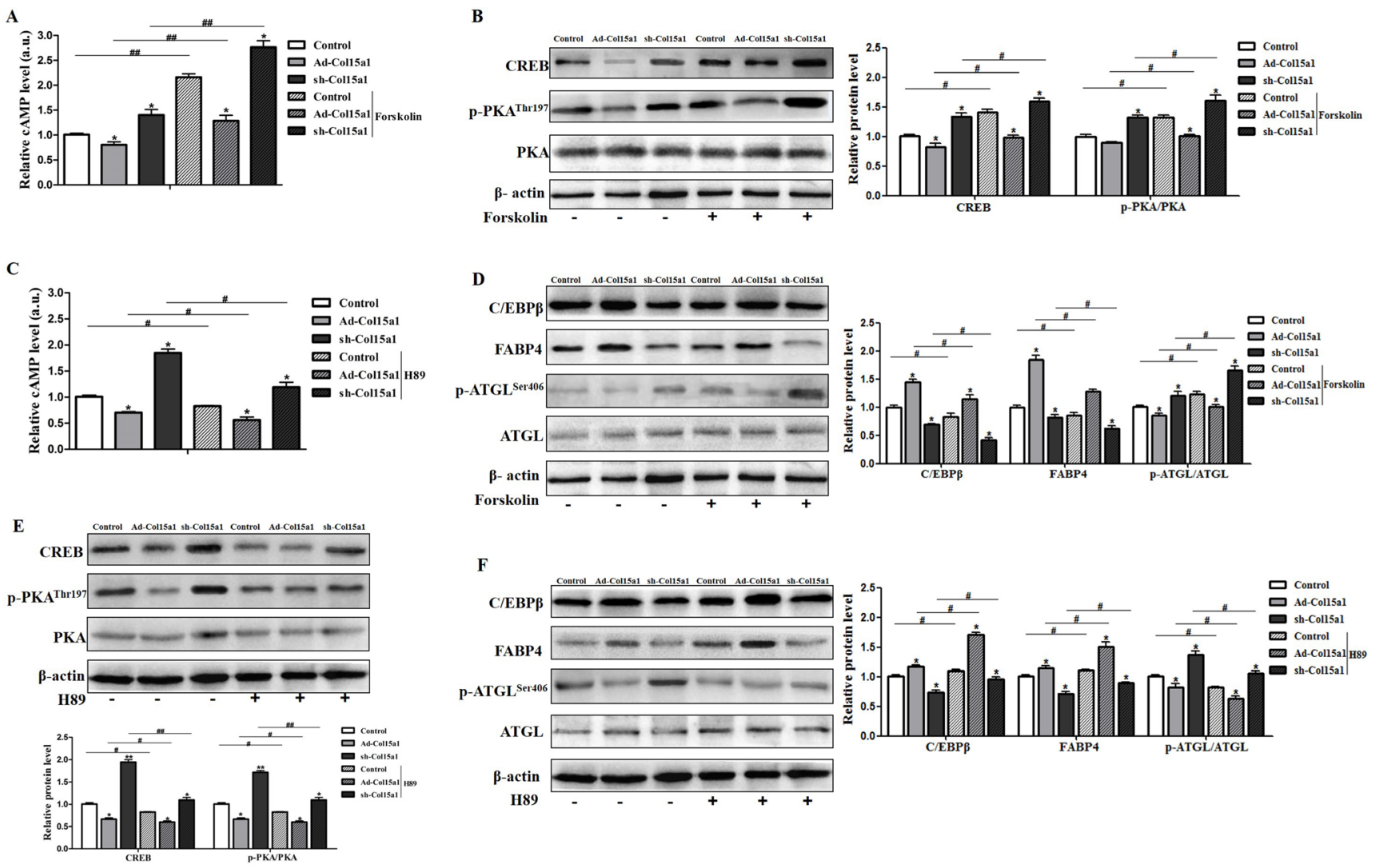

Figure 7: cAMP/PKA signal pathway was essential for effects of ColXV on adipocyte differentiation and lipolysis. Adipocytes were pre-infected with Ad-Col15 $\alpha 1$ and sh-Col15 $\alpha 1$ (Ad-GFP as control) for $72 \mathrm{~h}$. Part of those cells were incubated with $10 \mu \mathrm{M}$ Forskolin for $1 \mathrm{~h}$, then cAMP level (A) protein level of CREB, p-PKA/PKA (B) and C/EBP $\beta$, FABP4, ATGL, p-ATGL ${ }^{\text {Ser406 }}(\mathbf{D})$ were detected $(n=6)$. Another part of those cells were treated with $10 \mu \mathrm{M}$ H89 for $2 \mathrm{~h}$, followed by cAMP level (C) protein level of CREB, p-PKA and PKA $(\mathbf{E})$ and C/EBP $\beta$, FABP4, ATGL, p-ATGL ${ }^{\text {Ser406 }}(\mathbf{F})$ evaluation $(n=6)$. Data represent the mean \pm SEM of three independent experiments. ${ }^{* \#} P<0.05,{ }^{* * \#} P<0.01$. 
Previous study has shown collagen triple helix repeat containing 1 (Cthrc1) inhibits adipocyte differentiation by inhibiting PPAR $\gamma$ signaling and activating CREB [32], which is consistent with our findings CREB as a negative regulator in ColXV promoted adipocyte differentiation. Although some reports indicated that CREB participates in adipogenesis via positive transcriptional regulating $\mathrm{C} / \mathrm{EBP} \beta$ and PPAR $\gamma$ at early state $[33,34]$, we found CREB suppressed adipocyte differentiation dependent on ColXV. Moreover, CREB was found binding on $-354 \mathrm{bp}$ $\sim-334$ bp upstream of ColXV promoter, thus attenuate ColXV transcription and reverse the effects of ColXV on adipocyte differentiation and lipolysis.

An interesting observation from bisulfite sequencing was that lower methylation level presented both in promoter and intron 1 of ColXV after adipocytes differentiation. Past studies indicated that DNA methyltransferases are important in maintaining methylation patterns during adipocyte differentiation, altering fat tissue remodeling and ameliorating obesity-induced glucose intolerance and insulin resistance [35-37]. In our study, we found ColXV has a similar effect with 5-Aza-dC on decreasing Dnmt1 activity during adipocyte differentiation. Interestingly, we demonstrated ColXV had no effects on de novo methyltransferase activity, which is consistent with previous reports that inhibition of Dnmt1 but not Dnmt3a or Dnmt3b function by 5-aza-2-deoxycytidine is the principal means to reactivate genes [38]. Dnmt1, as an enzyme that responsible for maintaining DNA methylation, forms part of the family of DNA methyltransferase enzymes. The reduction of Dnmt1 expression could lead to a low methylation status for genes, including adipogenic and lipolytic genes, thus induce their expressions. So, we continued to investigate whether the inhibition of Dnmt1 activity by ColXV further influence adipocyte differentiation. Data show that adipocyte differentiation was promoted and lipolysis was decreased when ColXV was over-expressed and this effect was accordant with 5-Aza-dC. Our data suggested the down-regulation of Dnmt1 by ColXV could be one reason in its role in promoting adipocyte differentiation and inhibiting lipolysis.

The cAMP/PKA signal pathway has been reported to be involved in adipocyte lipolysis activation and adipocyte differentiation inhibition [39-41]. CREB is also activated by PKA-mediated phosphorylation and activation of PKA and CREB leads to the phosphorylation of HSL ${ }^{\text {Ser660 }}$ and

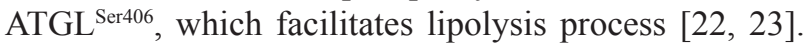
Because of the repressing effect of CREB on ColXV, we detected the role of $\mathrm{CAMP} / \mathrm{PKA}$ signal pathway in ColXV function. Results show that the promoting effect of

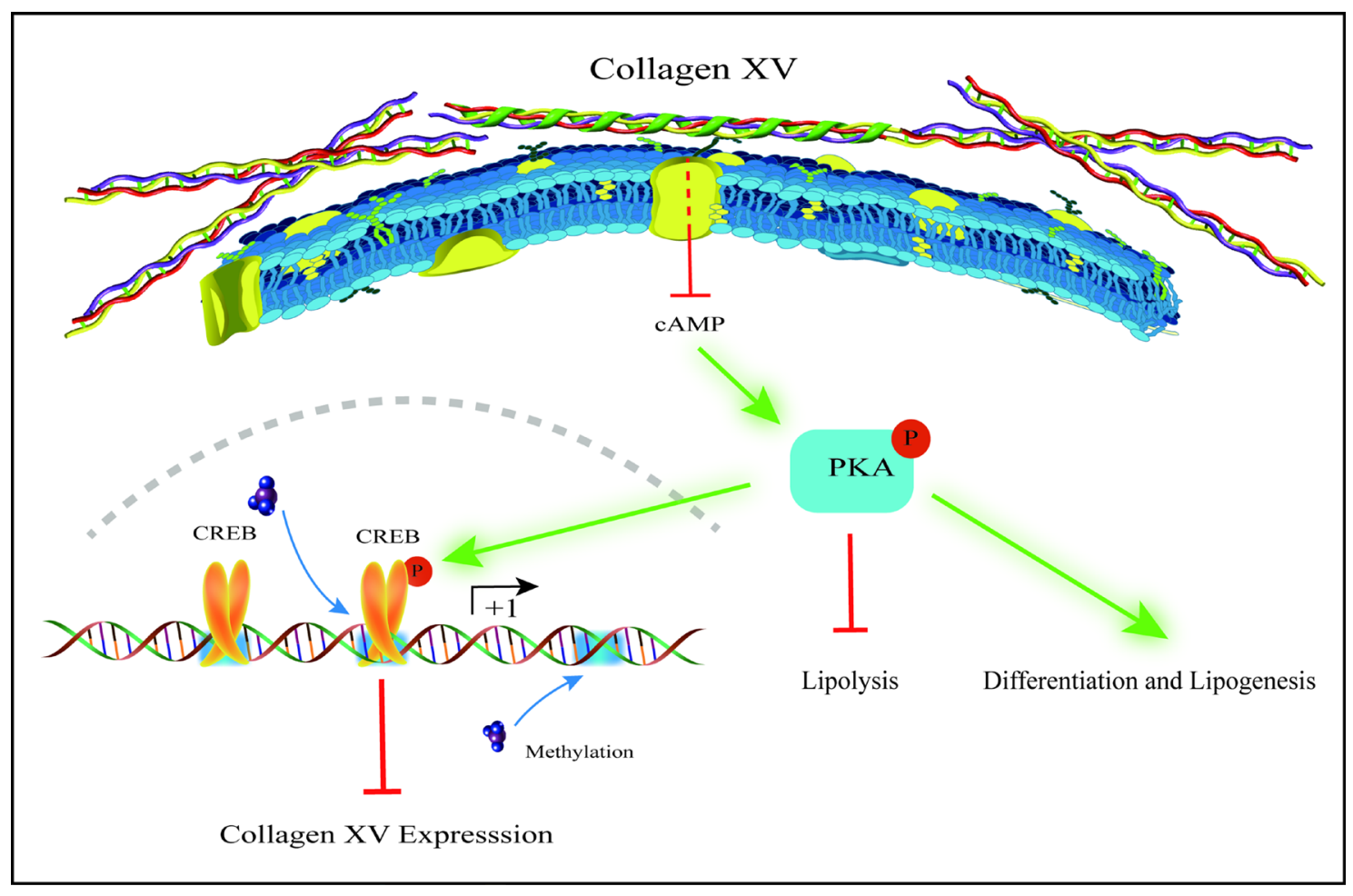

Figure 8: Proposed model for mechanism of CoIXV on adipocyte differentiation and lipolysis. ColXV expressions were increased in adipose tissues of obese mice and mature adipocytes. ColXV aggravated mice obesity. In vitro, ColXV promoted adipocyte differentiation and decreased adipocyte lipolysis. ColXV promoted adipocyte differentiation and enhanced lipolysis via inactivating the phosphorylation of cAMP/PKA signal pathway, and CREB reversed the effects of ColXV on adipocyte differentiation via binding its promoter. In addition, ColXV promoted adipocyte differentiation though inhibiting DNA methylation. Above all, ColXV accelerated adipocyte differentiation and inhibited lipolysis. 
ColXV on adipogenesis and repressing effect on lipolysis is through inhibiting cAMP/PKA signaling pathway, consistent our previous finding that $\mathrm{cAMP} / \mathrm{PKA}$ signal pathway activation inhibited adipogenic markers C/EBP $\beta$, PPAR $\gamma$ and FABP4 [42].

In summary, our findings provide compelling evidence that ColXV promoted adipocyte differentiation and inhibited lipolysis via cAMP/PKA pathway. Moreover, we found that CREB was a novel transcriptional suppressor of ColXV and reduce ColXV function of promoting adipocyte differentiation and alleviating lipolysis. ColXV could promote fat deposition and weaken lipolysis by inhibiting its DNA methylation (Figure 8). Our results might contribute to further understanding of regulatory mechanisms of adipocytes differentiation and lipolysis to seek for novel approaches to overcome obesity.

\section{MATERIALS AND METHODS}

\section{Animal experiments}

Two-week-old male Kunming mice were purchased from the Laboratory Animal Center of the Fourth Military Medical University. All mice were treated in accordance with the applicable guidelines and regulations approved by the Animal Ethics Committee of Northwest A\&F University. Mice were allowed to ad libitum water and standard chow diet (Control, fat provides $10 \%$ of total energy) or high fat diet (HFD, fat provides $60 \%$ of total energy) for 10 weeks. Body weight and food intake were recorded each week. The animal room was maintained in controlled conditions of temperature at $25 \pm 1{ }^{\circ} \mathrm{C}$, humidity at $55 \pm 5 \%$, and a $12 \mathrm{~h}$ light and $12 \mathrm{~h}$ dark cycle. After intraperitoneal injection of recombinant adenovirus overexpression vector of ColXV (Ad-Col15 1 1) and recombinant adenovirus interference vector of ColXV (sh-Col15 1 ) to HFD or chow diet fed mice for 10 days, mice were euthanized for collection of tissues and blood. eWAT, iWAT and BAT were sampled in epididymis, inguinal and interscapular adipose tissue, respectively.

\section{Body composition analysis}

Mouse body composition analysis of HFD or chow diet fed mice at 9 weeks old was performed using a small animal MRI (Echo Medical Systems, Houston, USA). Fat and lean depots were quantified ( $n=7 \sim 8$ per group).

\section{Cell culture}

Mouse primary adipocytes were harvested from epididymal white adipose tissues of four-week-old mice, and HEK293A and HEK293T cells were saved in our lab. Cells was maintained in proliferation medium (PM) containing Dulbecco's modified Eagle's-H21 medium/ Ham's F12 (DMEM/F12), 10\% FBS (Gibco, Carlsbad,
USA) and $1 \%$ penicillin-streptomycin in a humidified atmosphere of $5 \% \mathrm{CO}_{2}$ at $37^{\circ} \mathrm{C}$. To induce pre-adipocytes into mature adipocytes, cells were grown in differentiation medium (DM) containing $1 \mu \mathrm{M}$ dexamethasone (Sigma, MO, USA), $0.01 \mathrm{mg} / \mathrm{mL}$ insulin (Sigma, MO, USA), $0.5 \mathrm{mM}$ isobutylmethyl xanthine (Sigma, MO, USA), 10\% FBS (Gibco, Carlsbad, USA) and 1\% penicillinstreptomycin 2 days after confluence. After 2 days differentiation, cells were then maintained in DMEM/ F12, 10\% FBS, 1\% penicillin-streptomycin, and $0.01 \mathrm{mg} /$ $\mathrm{mL}$ insulin. Cells were differentiated after induction for 6 days.

\section{Chemical treatment and infection}

The recombinant adenovirus vector Ad-Col15 $\alpha 1$ and adenovirus interference vector sh-Col15 $\alpha 1$ were infected for $24 \mathrm{~h}$ or $48 \mathrm{~h}$ at the titer of $1 \times 10^{9} \mathrm{IFU} / \mathrm{mL}$ to test the effect of the changes of ColXV expression on adipocyte differentiation. Gene expressions of adipocyte differentiation and lipolysis makers were detected by Quantitative Real-Time PCR or Western blot. When testing the impact of ColXV on cAMP/ PKA signal pathway activated by Forskolin $(10 \mu \mathrm{M}$, Selleck, Houston, USA), differentiated adipocytes were treated with H89 (10 $\mu \mathrm{M}$, Selleck, Houston, USA) or DMSO (Promega, Madison, USA) $1 \mathrm{~h}$ prior to Forskolin $(10 \mu \mathrm{M})$, and samples were assessed by Western blot. Experimental procedure was as described in our previous reports in detail [42].

\section{Bodipy staining}

Bodipy (Invitrogen, Carlsbad, USA) with $513 \mathrm{~nm}$ green florescent was diluted with DMSO to a concentration of $1 \mathrm{~mm}$ as work solution. When differentiating for $6 \mathrm{~d}$, adipocyte lipid droplets were stained with Bodipy. In brief, cells were rinsed three times with PBS and then fixed in $10 \%$ (vol/vol) formaldehyde for $30 \mathrm{~min}$. The fixed cells were then washed three times in PBS and stained with a working solution of Bodipy for $30 \mathrm{~min}$ at room temperature. Cells were washed with PBS thrice and image observation was taken with an inverted microscope (Nikon Instruments Europe BV, England).

\section{Oil red O staining}

Lipid droplets were stained with Oil Red O staining as described in our previous publication [43]. Firstly, primary adipocytes were washed with PBS thrice, and then incubated in $4 \%$ formaldehyde for $30 \mathrm{~min}$ at room temperature. Then cells were gently washed with PBS thrice, stained with Oil Red O (Sigma, St. Louis, USA) for $30 \mathrm{~min}$, and incubated at $37^{\circ} \mathrm{C}$ temperature. Cells were washed in PBS for 3 times to remove unbounded dye, and then took photographs with Nikon TE2000-S florescent microscope. 
Table 1: Primers for quantitative real-time PCR

\begin{tabular}{|c|c|c|}
\hline Genes & Accession number & Primer sequences $\left(5^{\prime}\right.$ to $\left.3^{\prime}\right)$ \\
\hline $\mathrm{C} / \mathrm{EBP} \beta$ & NM_001287739.1 & $\begin{array}{l}\text { F: GCCCGTTGCCAGGCGCCGCCTTATAAA } \\
\text { R: GGCTCCAGGTAGGGGCTGAAGTCGA }\end{array}$ \\
\hline $\operatorname{PPAR} \gamma$ & NM_001001460 & $\begin{array}{l}\text { F: CGAATGCCACAAGCGGAGAAGG } \\
\text { R: CTTGGCTTTGGTCAGCGGGAA }\end{array}$ \\
\hline $\mathrm{C} / \mathrm{EBP} \alpha$ & NM_001031459 & $\begin{array}{l}\text { F: ATGGAGCAAGCCAACTTCTAC } \\
\text { R: GCCAGGAACTCGTCGTTGAA }\end{array}$ \\
\hline FABP4 & NM024406.2 & $\begin{array}{l}\text { F: AAGTGGGAGTGGGCTTTG } \\
\text { R: GTCGTCTGCGGTGATTTC }\end{array}$ \\
\hline FASN & NM_205155 & $\begin{array}{l}\text { F: AGTGTCCACCAACAAGCG } \\
\text { R: GATGCCGTCAGGTTTCAG }\end{array}$ \\
\hline $\mathrm{ACC} \alpha$ & NM_133360.2 & $\begin{array}{l}\text { F: GGATATCGCATCACAATTGGC } \\
\text { R: CCTCGGAGTGCCGTGCTCTGGATC }\end{array}$ \\
\hline HSL & NM_001039507.2 & $\begin{array}{l}\text { F: AGACACCAGCCAACGGATAC } \\
\text { R: GGGCATAGTAGGCCATAGCA }\end{array}$ \\
\hline ATGL & NM_001163689.1 & $\begin{array}{l}\text { F: GACCTGATGACCACCCTTTC } \\
\text { R: TGCTACCCGTCTGCTCTTT }\end{array}$ \\
\hline UCP1 & NM_009463.3 & $\begin{array}{l}\text { F: GCCAAAGTCCGCCTTCAGAT } \\
\text { R: TGATTTGCCTCTGAATGCCC }\end{array}$ \\
\hline Col15 $\alpha 1$ & NM_009928.3 & $\begin{array}{l}\text { F: TCCGAGATGGTTGGAAAAAG } \\
\text { R: AAATGGGGTTCAGTGGAGGT }\end{array}$ \\
\hline CREB & NM_133828.2 & $\begin{array}{l}\text { F: ACCCAGGGAGGAGCAATACAG } \\
\text { R: TGGGGAGGACGCCATAACA }\end{array}$ \\
\hline Dnmt1 & NM_001314011.1 & $\begin{array}{l}\text { F: GGGTCTCGTTCAGAGCTG } \\
\text { R: GCAGGAATTCATGCAGTAAG }\end{array}$ \\
\hline GAPDH & NM_001289726.1 & $\begin{array}{l}\text { F: AGGTCGGTGTGAACGGATTTG } \\
\text { R: TGTAGACCATGTAGTTGAGGTCA }\end{array}$ \\
\hline
\end{tabular}

\section{TG and FFA measurement}

Total protein content was measured with the DC assay (BioRad, USA) and triglycerides (TGs) in adipose tissue or adipocytes were analyzed by TG assay kit (Jiancheng, Nanjing, China). Free fatty acid (FFA) content was determined at absorption at $570 \mathrm{~nm}$ with FFA assay kit (Jiancheng, Nanjing, China). Determination methods of TG and FFA were consistent with our previous studies [44].

\section{Enzyme-linked immunosorbent (ELISA) assay}

Adipocytes and adipose tissue were collected as our study described previously [45]. Briefly, cells after Ad-Col15 $\alpha 1$ and sh-Col15 $\alpha 1$ infection for $96 \mathrm{~h}$ were collected and disrupted by ultrasonication $(28 \mathrm{KHz}, 30$ min). After induced differentiation for 4 days cAMP level in adipocytes and the protein level of FASN, ACC $\alpha$, ATGL and HSL in white adipose tissue were measured using commercial ELISA kits (R\&D Systems, USA).

\section{Lipolysis experiments in vitro}

Primary cultured adipocytes were serum-starved in Krebs-Ringer buffer containing HEPES (KRH buffer)
$\left(\mathrm{NaCl}\right.$ at $120 \mathrm{mM} ; \mathrm{KCl}$ at $4.7 \mathrm{mM} ; \mathrm{CaCl}_{2}$ at $2.2 \mathrm{mM}$; HEPES at $10 \mathrm{mM} ; \mathrm{KH}_{2} \mathrm{PO}_{4}$ at $1.2 \mathrm{mM} ; \mathrm{MgSO}_{4}$ at $1.2 \mathrm{mM}$; glucose at $5.4 \mathrm{mM}$ ) supplemented with $1 \%$ bovine serum albumin (BSA) fatty acid free (Roche, Switzerland) for $3 \mathrm{~h}$. Following starvation, the cells were incubated with $\mathrm{KRH}$ buffer containing 4\% BSA in the presence and absence of isoproterenol (Sigma, USA) at concentrations of $1 \mu \mathrm{M}$. All adipocytes lipolysis measurements were made over a $3 \mathrm{~h}$ period at $37^{\circ} \mathrm{C}$ and $5 \% \mathrm{CO}_{2}$.

\section{Promoter reporter assay and dual luciferase reporter assay}

Three fragments containing ColXV - 5' sequences $-1083 \mathrm{bp} \sim+40 \mathrm{bp},-712 \mathrm{bp} \sim+40 \mathrm{bp}$ and $-234 \mathrm{bp} \sim$ $+40 \mathrm{bp}$ relative to the transcription initiation site were sub-cloned into pGL3-basic vector, respectively (Takara, China). Mutant ColXV reporter plasmids were generated using the luciferase plasmid contained $-1083 \mathrm{bp}$ +40 bp fragment as a template, then a mutagenesis kit (Invitrogen, CA, USA) was used to created site-directed mutagenesis for two CREs, as described in our previous study [46]. HEK293T cells were cultured in 24-well plates and co-transfected with ColXV reporter plasmid 
and pRL-TK plasmid (control reporter), then treated with Forskolin or DMSO for $6 \mathrm{~h}$. Cells were harvested $48 \mathrm{~h}$ after transfection, and detected using the Dual-Luciferase Reporter assay system (Promega, USA). Dual luciferase reporter assay were as previously described [47].

\section{Bisulfite conversion and sequencing}

The methylation of ColXV was analyzed by bisulfite sequencing. Adipocyte and adipose tissue genomic DNA was extracted with Maxwell ${ }^{\circledR}$ RSC Cultured Cells DNA Kit (Promega, USA). Three DNA pools from each group were performed by sodium bisulfite treatment using the EZ DNA Methylation Kit (Zymo Research, USA). The primers were designed by online Methprimer software (http:/www.urogene.org/cgi-bin/ methprimer/methprimer.cgi). The primers in ColXV promoter for bisulfite sequencing PCR (BSP) were as follows: forward TTTATTGGATGGATGTTTTGGTAA, reverse CCACTTACATACCCCAAAATAACAC. While the primers in ColXV intron 1 were as follows: forward GAGGTGGTTGTTTTTTATTATTTT, reverse AACCCAAACACTCTTATATACCTTC. Modified genomic DNA was served as the template for PCR amplification immediately and PCR products were gel purified using Gel Purification Kit (Omega, USA). Then purified DNA were cloned into the pMD19-T vector (Takara, China) and then transformed into Escherichia coli. Later, competent cells were plated on lysogeny broth (LB) solid medium and identified by blue-white selection. Positive clones for each subject were randomly selected for sequencing (Invitrogen, China).

\section{DNMT activity assay}

Adipocytes were infected with recombinant adenovirus vector Ad-Col15 $\alpha 1$ and interference vector sh-Col15 $\alpha 1$. Another part of adipocytes were cultured in fresh complete culture medium with $10 \mu \mathrm{M} 5$-aza-dC as positive control. We detected DNMTs activity on nuclear extracts using $0.2 \mu \mathrm{g}$ of a synthetic 33 -bp hemi-methylated oligonucleotide containing $8 \mathrm{CGs}$ and $0.55 \mathrm{mCi}$ of $\mathrm{S}$-[methyl- $\left.{ }^{3} \mathrm{H}\right]$ adenosyl-L-methionine $\left(75 \mathrm{Ci} \mathrm{mmol}^{-1}\right)$ in a $20 \mathrm{mM}$ Tris- $\mathrm{HCl}$ (pH 7.6), 10 mM EDTA, 25\% glycerol and $1 \mathrm{mg} \mathrm{mL}^{-1}$ bovine serum albumin buffer. We stopped reactions using 12\% trichloroacetic acid, transferred samples onto a filter mat, washed them with cold $10 \%$ trichloroacetic acid, dried them and counted ${ }^{3} \mathrm{H}$ using a Wallac beta-counter.

\section{Quantitative real-time PCR analysis}

Total RNA was extracted with TRIpure Reagent kit (Takara, China). $500 \mathrm{ng}$ of total RNA was reverse transcribed using $\mathrm{M}-\mathrm{MLV}$ reverse transcriptase kit (Takara, China). Primers were designed as Table 1 in
Supplementary Data synthesized by Invitrogen (Shanghai, China). Quantitative PCR was performed in $20 \mu \mathrm{L}$ reaction system containing specific primers, cDNA and SYBR Premix EX Taq (Takara, China). The levels of mRNA were normalized using $\beta$-actin. The expressions of genes were analyzed by the method of $2^{-\Delta \Delta \mathrm{Ct}}$.

\section{Immunoblot analysis}

Adipocytes were solubilized in adipocyte lysing buffer. The solubilization was preceded for $40 \mathrm{~min}$ at $4{ }^{\circ} \mathrm{C}$, then the solution was centrifuged at $12,000 \mathrm{rpm}$ for $15 \mathrm{~min}$ at $4{ }^{\circ} \mathrm{C}$, and the supernatants were used for determination of protein concentration. Protein samples $(30 \mu \mathrm{g})$ were separated by electrophoresis on $12 \%$ and $5 \%$ SDS-PAGE gels using slab gel apparatus, and transferred to PVDF nitrocellulose membranes (Millipore, USA), blocked with 5\% skim milk powder/Tween 20/TBST at room temperature for $2 \mathrm{~h}$. The membranes were then incubated with primary antibodies against PPAR $\gamma$ (Ap0686), HSL (BS2742), ACC $\alpha$ (BS1378), $\beta$-actin (Ap0060) (Bioworld, CA, USA), C/EBP $\beta$ (ab32098), FABP4 (ab92501), ATGL (ab109251), CREB (ab7540), FASN (ab128856), PKA (ab108385), p-PKA ${ }^{\text {Thr197 }}$ (ab75991), Col15 1 1 (ab150463), p-ATGL ${ }^{\text {Ser406 }}$ (ab135093) (Abcam, Cambridge, UK), p-HSL ${ }^{\text {Ser660 }}$ (4126) (Cell Signaling Technology, MA, USA) at $4^{\circ} \mathrm{C}$ overnight. Following this step, the appropriate HRPconjugated secondary antibodies (Boaoshen, China) were added and incubated for $2 \mathrm{~h}$ at room temperature. Proteins were visualized using chemiluminescent peroxidase substrate (Millipore, USA), and then the blots were quantified using ChemiDoc XRS system (Bio-Rad, USA). Experimental procedure was as described previously [48].

\section{Statistical analysis}

Statistical analyses were conducted by SAS v8.0 (SAS Institute, Cary, NC). Data were analyzed using either one-way ANOVA or two-way ANOVA depending on the number of variables. Comparisons among individual means were made by Fisher's least significant difference (LSD). Data were presented as mean \pm SEM. $P<0.05$ was considered to be significant.

\section{CONFLICTS OF INTEREST}

The authors declare that no conflicts of interest exists.

\section{GRANT SUPPORT}

This work was supported by the grants from the Major National Scientific Research Projects (2015CB943102) and the National Nature Science Foundation of China (31572365). 


\section{REFERENCES}

1. Chu AY, Deng X, Fisher VA, Drong A, Zhang Y, Feitosa MF, Liu CT, Weeks O, Choh AC, Duan Q, Dyer TD, Eicher JD, Guo X, et al. Multiethnic genome-wide meta-analysis of ectopic fat depots identifies loci associated with adipocyte development and differentiation. Nat Genet. 2017; 49:125-30.

2. Huang Y, Gao S, Chen J, Albrecht E, Zhao R, Yang $\mathrm{X}$. Maternal butyrate supplementation induces insulin resistance associated with enhanced intramuscular fat deposition in the offspring. Oncotarget. 2017; 8:13073-84. https://doi.org/10.18632/oncotarget.14375.

3. Thondam SK, Daousi C, Wilding JP, Holst JJ, Ameen GI, Yang C, Whitmore C, Mora S, Cuthbertson DJ. Glucosedependent insulinotropic polypeptide promotes lipid deposition in subcutaneous adipocytes in obese type 2 diabetes patients: a maladaptive response. Am J Physiol Endocrinol Metab. 2017; 312:E224-33.

4. Lodhi IJ, Semenkovich CF. Peroxisomes: a nexus for lipid metabolism and cellular signaling. Cell Metab. 2014; 19:380-92.

5. Herzig S, Long F, Jhala US, Hedrick S, Quinn R, Bauer A, Rudolph D, Schutz G, Yoon C, Puigserver P, Spiegelman $\mathrm{B}$, Montminy M. CREB regulates hepatic gluconeogenesis through the coactivator PGC-1. Nature. 2001; 413:179-83.

6. Meng W, Liang X, Chen H, Luo H, Bai J, Li G, Zhang Q, Xiao T, He S, Zhang Y, Xu Z, Xiao B, Liu M, et al. Rheb inhibits beiging of white adipose tissue via PDE4D5dependent downregulation of the cAMP-PKA signaling pathway. Diabetes. 2017; 66:1198-213.

7. Theocharis AD, Skandalis SS, Gialeli C, Karamanos NK. Extracellular matrix structure. Adv Drug Deliv Rev. 2016; 97:4-27.

8. Mori S, Kiuchi S, Ouchi A, Hase T, Murase T. Characteristic expression of extracellular matrix in subcutaneous adipose tissue development and adipogenesis; comparison with visceral adipose tissue. Int J Biol Sci. 2014; 10:825-33.

9. Lin D, Chun TH, Kang L. Adipose extracellular matrix remodelling in obesity and insulin resistance. Biochem Pharmacol. 2016; 119:8-16.

10. Lee MH, Goralczyk AG, Kriszt R, Ang XM, Badowski C, Li Y, Summers SA, Toh SA, Yassin MS, Shabbir A, Sheppard A, Raghunath M. ECM microenvironment unlocks brown adipogenic potential of adult human bone marrow-derived MSCs. Sci Rep. 2016; 6:21173.

11. Iozzo RV, Schaefer L. Proteoglycan form and function: a comprehensive nomenclature of proteoglycans. Matrix Biol. 2015; 42:11-55.

12. Kadler KE, Baldock C, Bella J, Boot-Handford RP. Collagens at a glance. J Cell Sci. 2007; 120:1955-58.

13. Rygh CB, Løkka G, Heljasvaara R, Taxt T, Pavlin T, Sormunen R, Pihlajaniemi T, Curry FR, Tenstad O, Reed $\mathrm{RK}$. Image-based assessment of microvascular function and structure in collagen XV- and XVIII-deficient mice. J Physiol. 2014; 592:325-36.
14. Zaferani A, Talsma DT, Yazdani S, Celie JW, Aikio M, Heljasvaara R, Navis GJ, Pihlajaniemi T, van den Born J. Basement membrane zone collagens XV and XVIII/ proteoglycans mediate leukocyte influx in renal ischemia/ reperfusion. PLoS One. 2014; 9:e106732.

15. Mouw JK, Ou G, Weaver VM. Extracellular matrix assembly: a multiscale deconstruction. Nat Rev Mol Cell Biol. 2014; 15:771-85.

16. Inoue-Murayama M, Sugimoto Y, Niimi Y, Aso H. Type XVIII collagen is newly transcribed during bovine adipogenesis. Differentiation. 2000; 65:281-85.

17. Aikio M, Elamaa H, Vicente D, Izzi V, Kaur I, Seppinen L, Speedy HE, Kaminska D, Kuusisto S, Sormunen R, Heljasvaara R, Jones EL, Muilu M, et al. Specific collagen XVIII isoforms promote adipose tissue accrual via mechanisms determining adipocyte number and affect fat deposition. Proc Natl Acad Sci USA. 2014; 111:E3043-52.

18. Bishop JR, Passos-Bueno MR, Fong L, Stanford KI, Gonzales JC, Yeh E, Young SG, Bensadoun A, Witztum JL, Esko JD, Moulton KS. Deletion of the basement membrane heparan sulfate proteoglycan type XVIII collagen causes hypertriglyceridemia in mice and humans. PLoS One. 2010; 5:e13919.

19. Clementz AG, Mutolo MJ, Leir SH, Morris KJ, Kucybala K, Harris H, Harris A. Collagen XV inhibits epithelial to mesenchymal transition in pancreatic adenocarcinoma cells. PLoS One. 2013; 8:e72250.

20. Lim JM, Sherling D, Teo CF, Hausman DB, Lin D, Wells L. Defining the regulated secreted proteome of rodent adipocytes upon the induction of insulin resistance. J Proteome Res. 2008; 7:1251-63.

21. Mariman EC, Wang P. Adipocyte extracellular matrix composition, dynamics and role in obesity. Cell Mol Life Sci. 2010; 67:1277-92.

22. Kuang J, Zhang Y, Liu Q, Shen J, Pu S, Cheng S, Chen L, Li H, Wu T, Li R, Li Y, Zou M, Zhang Z, et al. Fat-specific Sirt6 ablation sensitizes mice to high-fat diet-induced obesity and insulin resistance by inhibiting lipolysis. Diabetes. 2017; 66:1159-71.

23. Su CL, Sztalryd C, Contreras JA, Holm C, Kimmel AR, Londos C. Mutational analysis of the hormone-sensitive lipase translocation reaction in adipocytes. J Biol Chem. 2003; 278:43615-19.

24. Cheishvili D, Christiansen S, Stochinsky R, Pepin AS, Sapozhnikov DM, Zhou R, Schmeltzer L, Dymov S, Szyf M. DNA methylation controls unmethylated transcription start sites in the genome in trans. Epigenomics. 2017; 9:611-33.

25. Chen YS, Wu R, Yang X, Kou S, MacDougald OA, Yu L, Shi H, Xue B. Inhibiting DNA methylation switches adipogenesis to osteoblastogenesis by activating Wnt10a. Sci Rep. 2016; 6:25283.

26. Sun K, Tordjman J, Clément K, Scherer PE. Fibrosis and adipose tissue dysfunction. Cell Metab. 2013; 18:470-77.

27. Crewe C, An YA, Scherer PE. The ominous triad of adipose tissue dysfunction: inflammation, fibrosis, and impaired angiogenesis. J Clin Invest. 2017; 127:74-82. 
28. Liu Y, Aron-Wisnewsky J, Marcelin G, Genser L, Le Naour G, Torcivia A, Bauvois B, Bouchet S, Pelloux V, Sasso M, Miette V, Tordjman J, Clément K. Accumulation and Changes in Composition of Collagens in Subcutaneous Adipose Tissue After Bariatric Surgery. J Clin Endocrinol Metab. 2016; 101:293-304.

29. Fenech M, Gavrilovic J, Malcolm P, Toms A, Turner J. The role of metalloproteinases and their tissue inhibitors in adipose tissue remodelling and whole-body lipid distribution: a cross-sectional clinical study. Lancet. 2015 (Suppl 1); 385:S36.

30. Ojima K, Oe M, Nakajima I, Muroya S, Nishimura T. Dynamics of protein secretion during adipocyte differentiation. FEBS Open Bio. 2016; 6:816-26.

31. Molina H, Yang Y, Ruch T, Kim JW, Mortensen P, Otto T, Nalli A, Tang QQ, Lane MD, Chaerkady R, Pandey A. Temporal profiling of the adipocyte proteome during differentiation using a five-plex SILAC based strategy. J Proteome Res. 2009; 8:48-58.

32. Stohn JP, Wang Q, Siviski ME, Kennedy K, Jin YR, Kacer D, DeMambro V, Liaw L, Vary CP, Rosen CJ, Prudovsky I, Lindner V. Cthrc1 controls adipose tissue formation, body composition, and physical activity. Obesity (Silver Spring). $2015 ; 23: 1633-42$.

33. Zhang JW, Klemm DJ, Vinson C, Lane MD. Role of CREB in transcriptional regulation of CCAAT/enhancer-binding protein beta gene during adipogenesis. J Biol Chem. 2004; 279:4471-78.

34. Fox KE, Fankell DM, Erickson PF, Majka SM, Crossno JT Jr, Klemm DJ. Depletion of cAMP-response elementbinding protein/ATF1 inhibits adipogenic conversion of 3T3-L1 cells ectopically expressing CCAAT/enhancerbinding protein $(\mathrm{C} / \mathrm{EBP})$ alpha, $\mathrm{C} / \mathrm{EBP}$ beta, or PPAR gamma 2. J Biol Chem. 2006; 281:40341-53.

35. Londoño Gentile T, Lu C, Lodato PM, Tse S, Olejniczak SH, Witze ES, Thompson CB, Wellen KE. DNMT1 is regulated by ATP-citrate lyase and maintains methylation patterns during adipocyte differentiation. Mol Cell Biol. 2013; 33:3864-78.

36. Parrillo L, Costa V, Raciti GA, Longo M, Spinelli R, Esposito R, Nigro C, Vastolo V, Desiderio A, Zatterale F, Ciccodicola A, Formisano P, Miele C, et al. Hoxa5 undergoes dynamic DNA methylation and transcriptional repression in the adipose tissue of mice exposed to high-fat diet. Int J Obes. 2016; 40:929-37.

37. Kim AY, Park YJ, Pan X, Shin KC, Kwak SH, Bassas AF, Sallam RM, Park KS, Alfadda AA, Xu A, Kim JB. Obesityinduced DNA hypermethylation of the adiponectin gene mediates insulin resistance. Nat Commun. 2015; 6:7585.
38. Robert MF, Morin S, Beaulieu N, Gauthier F, Chute IC, Barsalou A, MacLeod AR. DNMT1 is required to maintain $\mathrm{CpG}$ methylation and aberrant gene silencing in human cancer cells. Nat Genet. 2003; 33:61-65.

39. Xu H, Fu JL, Miao YF, Wang CJ, Han QF, Li S, Huang SZ, Du SN, Qiu YX, Yang JC, Gustafsson JÅ, Breyer RM, Zheng F, et al. Prostaglandin E2 receptor EP3 regulates both adipogenesis and lipolysis in mouse white adipose tissue. $\mathrm{J}$ Mol Cell Biol. 2016; 8:518-29.

40. Chen W, Chang B, Saha P, Hartig SM, Li L, Reddy VT, Yang Y, Yechoor V, Mancini MA, Chan L. Berardinelliseip congenital lipodystrophy $2 /$ seipin is a cell-autonomous regulator of lipolysis essential for adipocyte differentiation. Mol Cell Biol. 2012; 32:1099-111.

41. Fredriksson JM, Nedergaard J. Norepinephrine specifically stimulates ribonucleotide reductase subunit R2 gene expression in proliferating brown adipocytes: mediation via a cAMP/PKA pathway involving Src and Erk1/2 kinases. Exp Cell Res. 2002; 274:207-15.

42. Gan L, Liu Z, Chen Y, Dan Luo, Feng F, Liu G, Sun C. $\alpha-\mathrm{MSH}$ and Foxc2 promote fatty acid oxidation through $\mathrm{C} / \mathrm{EBP} \beta$ negative transcription in mice adipose tissue. Sci Rep. 2016; 6:36661.

43. Liu Z, Gan L, Liu G, Chen Y, Wu T, Feng F, Sun C. Sirt1 decreased adipose inflammation by interacting with Akt2 and inhibiting mTOR/S6K1 pathway in mice. J Lipid Res. 2016; 57:1373-81.

44. Liu G, Li M, Saeed M, Xu Y, Ren Q, Sun C. $\alpha$ MSH inhibits adipose inflammation via reducing FoxOs transcription and blocking Akt/JNK pathway in mice. Oncotarget. 2017; 8:47642-47654. https://doi.org/10.18632/ oncotarget. 17465 .

45. Cao W, Li M, Wu T, Feng F, Feng T, Xu Y, Sun C. aMSH prevents ROS-induced apoptosis by inhibiting Foxo1/ mTORC2 in mice adipose tissue. Oncotarget. 2017; 8:40872-40884. https://doi.org/10.18632/oncotarget.16606.

46. Liu Z, Gan L, Xu Y, Luo D, Ren Q, Wu S, Sun C. Melatonin alleviates inflammasome-induced pyroptosis through inhibiting NF- $\mathrm{kB} / \mathrm{GSDMD}$ signal in mice adipose tissue. J Pineal Res. 2017; 63:e12414.

47. Gan L, Liu Z, Cao W, Zhang Z, Sun C. FABP4 reversed the regulation of leptin on mitochondrial fatty acid oxidation in mice adipocytes. Sci Rep. 2015; 5:13588.

48. Liu Z, Gu H, Gan L, Xu Y, Feng F, Saeed M, Sun C. Reducing Smad3/ATF4 was essential for Sirt1 inhibiting ER stress-induced apoptosis in mice brown adipose tissue. Oncotarget. 2017; 8:9267-79. https://doi.org/10.18632/ oncotarget. 14035 . 